\title{
Behavior of Phosphoric Acid Anodized Oxide on Aluminum in Phosphate Buffer Solutions
}

\author{
Phan Trung Thanh*, Akitane AKIYAMA* and Takashi SAJI*
}

\begin{abstract}
Behavior of anodic oxide films formed on $1100-\mathrm{Al}$ in a phosphoric acid bath have been investigated in phosphate buffer solutions of $\mathrm{pH} 1.40,6.23,11.30$ and an Al saturated neutral phosphate solution. The amount of dissolved Al ions into the buffer solutions, the open circuit potential and the polarization resistance were measured as a function of immersion time. The results were compared with those of anodic oxide films formed in a sulfuric acid bath for more detailed discussions. It was found that the phosphoric acid anodized (PAA) oxide films were more corrosion resistive in acidic and alkaline buffer solutions than the sulfuric acid anodized films. However, in a neutral solution, the results were opposite and were explained by the degradation converging upon active sites within the PAA oxide. The open circuit potential transients were interpreted by the distribution profiles of $\mathrm{Al}, \mathrm{P}$ and $\mathrm{S}$ within the anodic oxides which were analyzed by an X-ray micro-analyzer.
\end{abstract}

\section{Introduction}

Anodized aluminum finds increasing use in building and aerospace industries because of its excellent corrosion resistance and other abilities. The surface preparation of aluminum for adhesive bonding receiving great interest in the aircraft industry is anodization in phosphoric

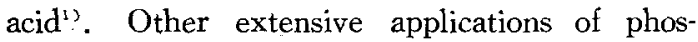
phoric acid anodized (PAA) aluminum are found for $\mathrm{Al}$ print plate $^{2)}$ and for electroplating of various metal $^{3,4}$ ).

In the past, most investigations of PAA aluminum were on the film formation kinetic $^{5,6)}$, on the film structure ${ }^{7-9)}$ and on the chemical and physical properties ${ }^{10)}$. The structure of the PAA oxide consists generally of duplex layers: a porous top layer constructed of closely packed columnar cells, each with a central pore, and a simple dense layer of uniform thickness, as so-called barrier layer ${ }^{7)}$. This is a common structure of porous-type anodic oxides formed in various acidic electrolytes, e.g. sulfuric acid, chromic acid, phosphoric acid, etc. However, it is found strictly that there were many differences in the morphology, the chemical and electrochemical natures and other characteristics of these oxides. The electroplating of various metal on the PAA oxide films has been investi-

\footnotetext{
* Tokyo Institute of Technology, Graduate School at Nagatsuta (4259 Nagatsuta-cho, Midori-ku, Yokohama)

Key Words: Phosphoric Acid Anodized Aluminum, Anodic Oxide on Aluminum, Dissolution in Phosphate Buffer Solutions;
}

gated in our laboratory, in comparison with the oxide films formed in sulfuric $\mathrm{acid}^{3}$. Recently, the investigations on the morphology and crystalline structures of the two oxide films have been described by Thompson, et al. ${ }^{7,11}$. However, there is a paucity of literature on the chemical and electrochemical natures of the PAA oxide film. Lack of information on these natures has contributed to obscurity in the oxide growth mechanism and to uncertainty in predicting the durability of PAA oxides for industrial applications.

A number of works have been done regarding the electrochemical behavior and structure of the $\mathrm{Al}$ anodic oxide film formed in a neutral borate solution using the same solution ${ }^{12)}$, and regarding the hydrogen evolution reaction on the Al hydrated oxide in a weak acidic acetate solution $^{13}$. It should be noted that $\mathrm{Al}$ ions have a comparatively high solubility in the borate electrolyte and this fact can be explained by taking into account the formation of soluble complexes between $\mathrm{Al}$ and anions. The electrolytes chosen in the present work are phosphate buffer solutions, not only because the PAA oxide film contains phosphate ions, but also because of its buffer action in three acidic, neutral and alkaline regions.

The purpose of this work is to investigate the behavior of the PAA oxide film in the phosphate buffer solutions and, as shown later, the aluminum saturated neutral phosphate solution is found as a new, suitable electrolyte in the electrochemical study. The results are co- 
mpared with those of anodic oxide films formed in sulfuric acid for more detailed discussions.

\section{Experimental}

\subsection{Electrode}

A rod of commercially pure $\mathrm{Al}(1100-\mathrm{Al})$ containing $0.2 \% \mathrm{Cu}, 1 \% \mathrm{Si}$ and $\mathrm{Fe}, 0.1 \%$ $\mathrm{Mn}$ and $0.1 \% \mathrm{Zn}$ as major impurities was cut into cylinder of approximately $1 \mathrm{~cm}$ long and $1 \mathrm{~cm}$ in diameter. The electrode was center drilled and attached to a stainless steel mounting rod and three teflon compression gaskets ${ }^{14}$. Before use, the electrode was abraded with $\mathrm{SiC}$ paper from $\# 800$ to $\# 1500$, cleaned by an ultrasonic rinse in distilled water and stored in a desiccator. The aluminum-teflon electrode assembly, before anodizing, was degreased at $65^{\circ} \mathrm{C}$ in $1.13 \mathrm{M} \mathrm{NaOH}$ solution for $10 \mathrm{~s}$, rinsed for 2 min with gentle agitation in distilled water and transferred into the anodizing bath without drying.

\subsection{Anodizing}

Anodic oxide films were formed in $3.57 \mathrm{M}$ $\mathrm{H}_{3} \mathrm{PO}_{4}$ and in $2.83 \mathrm{M} \mathrm{H}_{2} \mathrm{SO}_{4}$ solutions at $25 \pm$ $1^{\circ} \mathrm{C}$ with a cylindrical lead cathode. The operating conditions for anodizing are shown in Table 1. The electrolyte was agitated with a magnetic teflon stirrer during experiment. The electrode anodized in the phosphoric acid bath and in the sulfuric acid bath was named $\mathrm{P}$ and $\mathrm{S}$ electrode, respectively. The electrode represented by $A$ was not anodized and the surface was covered by a very thin air-formed film ${ }^{13}$.

\subsection{Polarization}

The polarization experiments were performed in a six neck polarization cell ${ }^{14)}$ with two platinum counter electrodes and a mercurous phosphate reference electrode (MPE, $E_{0}=649.3 \mathrm{mV}$ vs. NHE at $25^{\circ} \mathrm{C}$ ). Both the cell and the MPE were kept in a thermostat bath at $25.0_{ \pm}$ $0.1^{\circ} \mathrm{C}$. Three buffer electrolytes (total concentration $0.5 \mathrm{M}$ ) were prepared from reagent grade phosphoric acid and its sodium salts and the $\mathrm{pH}$ values were $1.40,6.23$ and 11.30 . The experiments were also carried out in an aluminum saturated neutral solution $(\mathrm{pH} 6.23)$ containing $20 \mathrm{mg} \mathrm{dm}^{-3} \mathrm{Al}$ ion. Dissolved oxygen was removed by bubbling nitrogen gas before and during experiment.

The anodized electrode was rinsed in distilled water for $1 \mathrm{~min}$ and immersed immediately in the polarizing electrolyte. The open circuit potential $\left(\varepsilon_{\mathrm{ocp}}\right)$ was recorded through a high input impedance voltage follower and displayed by a digital voltmeter. The electrode potential reported refers to the MPE. The polarization resistance $\left(R_{\mathrm{p}}\right)$ measurement was conducted intermittently for 2 days by applying very small constant cds (ca. $10^{-5} \mathrm{~A} / \mathrm{m}^{2}$ ) for $15 \mathrm{~s}$ causing overvoltages within $\pm 5 \mathrm{mV}$. This polarizing time was chosen, not only because it caused no appreciable change in the film nature during polarization, but also because it was long enough to charge up the double layer ${ }^{15)}$. The $R_{\mathrm{p}}$ values were calculated from the slope of the

Table 1 Anodizing conditions, film thicknesses $(\theta)$ and amounts of $\mathrm{Al}$ within oxide films $\left(C_{\mathrm{o}}\right)$

\begin{tabular}{|c|c|c|c|c|c|c|c|}
\hline \multicolumn{2}{|c|}{ Electrode } & $\begin{array}{l}\text { Anodizing } \\
\mathrm{cd} / \mathrm{Am}^{-2}\end{array}$ & $\begin{array}{c}\text { Anodizing } \\
\text { time/min }\end{array}$ & $\begin{array}{l}\text { Anodizing } \\
\text { voltage } / \mathrm{V}\end{array}$ & $\begin{array}{c}\text { Thickness } \\
\theta / \mu \mathrm{m}\end{array}$ & $C_{\mathrm{o}} / \mathrm{mg} \mathrm{dm}^{-3}$ & $C_{0} \times \theta^{-1}$ \\
\hline \multirow{5}{*}{ 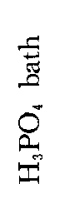 } & $\mathrm{P} 1$ & 100 & 20 & 66.0 & 8.5 & 11.2 & 1.3 \\
\hline & $\mathrm{P} 2$ & 100 & 40 & 65.0 & 8.5 & 12.4 & 1.5 \\
\hline & P3 & 100 & 60 & 65.5 & 9.0 & 12.6 & 1.4 \\
\hline & $\mathrm{P} 4$ & 130 & 30 & 82.0 & 7.8 & 13.2 & 1.7 \\
\hline & P 5 & 50 & 80 & 40.0 & 3.9 & 6.3 & 1.6 \\
\hline \multirow{5}{*}{ 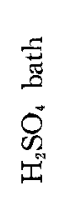 } & $\mathrm{S} 1$ & 100 & 20 & 9.1 & 2.9 & 24.4 & 8.4 \\
\hline & $\mathrm{S} 2$ & 100 & 40 & 10.0 & 10.0 & 57.2 & 5.7 \\
\hline & S3 & 100 & 60 & 11.0 & 14.9 & 71.8 & 4.8 \\
\hline & $\mathrm{S} 4$ & 130 & 30 & 13.0 & 10.2 & 58.2 & 5.7 \\
\hline & S5 & 50 & 80 & 6.4 & 10.9 & 53.6 & 4.9 \\
\hline \multicolumn{2}{|c|}{$\mathrm{A}$} & 0 & 0 & - & - & - & - \\
\hline
\end{tabular}


linear polarization curve.

\subsection{Chemical analysis}

The amount of dissolved $\mathrm{Al}$ ion $\left(C_{\mathrm{d}}\right)$ into the buffer solutions was determined as a function of immersion time by analyzing the solution sample of $2 \mathrm{~cm}^{3}$ with an oxinate extraction method $^{16)}$. The $\mathrm{pH}$ of each solution sample was adjusted with $2 \mathrm{M}$ sodium acetate solution to 9.00 just before the extraction in order to avoid interference of phosphorus. The absorbance of the chloroform extract was read with a spectrophotometer at $390 \mathrm{~nm}$ after removing droplets of water by $1 \mathrm{~g}$ of anhydrous sodium sulfate crystal. The calibration curve was obtained with a standard solution of potassium alum. Furthermore, the amount of $\mathrm{Al}$ contained in anodic oxide $\left(C_{0}\right)$ was measured by dissolving oxide film into the well-known stripping solution of $5 \% \mathrm{H}_{3} \mathrm{PO}_{4}$ and $4 \% \mathrm{~K}_{2} \mathrm{Cr}_{2} \mathrm{O}_{7}$ solution at $85^{\circ} \mathrm{C}$ for $30 \mathrm{~s}$ and analyzing with the above method. The results are also listed in Table 1.

\section{$2.5 X$-ray microanalyzer (EPMA) analy- sis}

The distributions of $\mathrm{Al}, \mathrm{P}$ and $\mathrm{S}$ in the cross-sectional view of anodic oxide film were measured by EPMA analysis. A thin vacuum evaporated coating was prepared on the sample cross-section embedded in epoxy resin. The incident electron beam of about $200 \AA$ in $\mathrm{di}$ ameter produced informations within a region of $1 \sim 2 \mu \mathrm{m}$ in depth and in diameter.

\section{Results}

Depending on the anodizing bath, a typical open circuit potential $\left(\varepsilon_{\text {ocp }}\right)$ transient of the $\mathrm{P}$ and $\mathrm{S}$ anodic oxide electrodes in the alkaline polarizing electrolyte has one of the two patterns shown respectively in Figs. 1 and 2 (solid lines). The $\varepsilon_{\text {ocp }}$ transient of $\mathrm{A}$ electrode is also shown in the figures (dotted lines). The amounts of $\mathrm{Al}$ ion dissolved into the polarizing electrolyte during immersion $\left(C_{\mathrm{d}}\right)$ are also shown in the figures in comparison with that of $A$ electrode. The vertical broken line $\left(t_{\mathrm{h}}\right)$ in the figures represents the time of hydrogen evolution seen with the naked eye. Both Figs. 1 and 2 share several features in common. (1) The $\varepsilon_{\text {ocp }}$ has a sharp decrease towards the cathodic direction immediately upon immersion and a nearly constant value in the final stage.

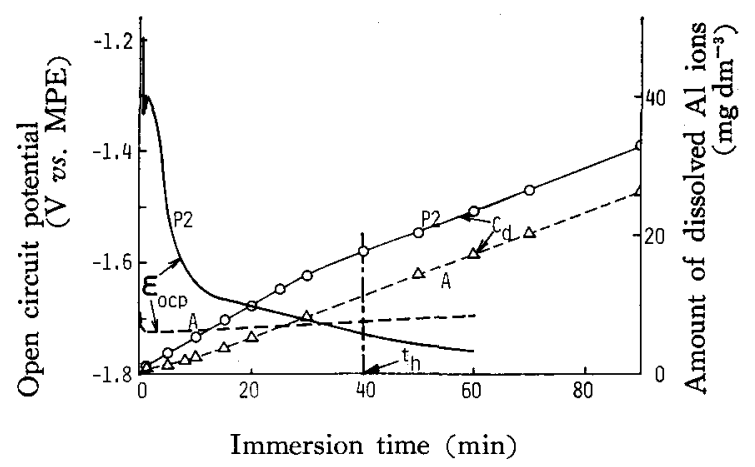

Fig. 1 Open circuit potential $\left(\varepsilon_{\text {ocp }}\right)$ and amount of dissolved $\mathrm{Al}$ ions $\left(C_{\mathrm{d}}\right)$ of $\mathrm{P}$ electrodes in the alkaline buffer solution (solid lines)

Anodizing conditions: $100 \mathrm{~A} / \mathrm{m}^{2}, 40 \mathrm{~min}$ (P 2). The dotted lines represent the results of the non-anodized electrode (A)

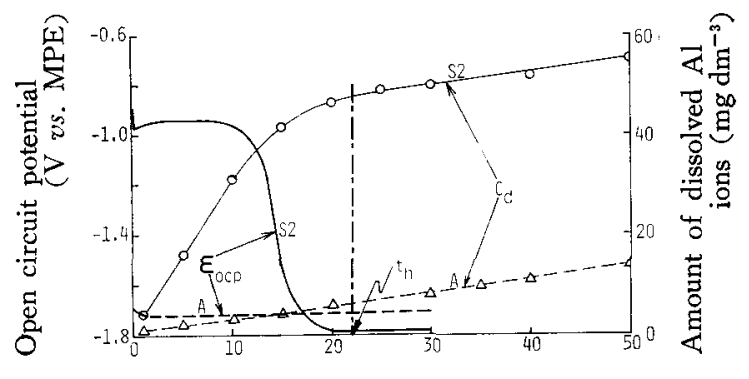

Immersion time (min)

Fig. 2 Open circuit potential $\left(\varepsilon_{\text {ocp }}\right)$ and amount of dissolved $\mathrm{Al}$ ions $\left(C_{\mathrm{d}}\right)$ of $\mathrm{S}$ electrodes in the alkaline buffer solution (solid lines)

Anodizing conditions: $100 \mathrm{~A} / \mathrm{m}^{2}, 40 \mathrm{~min}$ (S 2). The dotted lines represent the results of the non-anodized electrode (A)

(2) The $C_{\mathbf{d}}$ increases steadily with the immersion time in the first stage, i.e. the dissolution rate is constant, but it changes to a smaller value in the later stage. The final dissolution rate is exactly same as that observed for A electrode.

In addition to the above common features, each of the two patterns has its distinct characteristics. Figure 1 (for $\mathrm{P}$ electrode) shows a gradual decrease of the $\varepsilon_{\text {ocp }}$, but the $\varepsilon_{\text {ocp }}$ in Fig. 2 (for $\mathrm{S}$ electrode), in contrast, has a plateau at about $-1.0 \mathrm{~V}$ before the sharp decay towards the final steady value. Furthermore, 
the $C_{\mathrm{d}}$ of the $\mathrm{S}$ electrode, at a certain time, is greater than that of the $\mathrm{P}$ electrode.

The same $\varepsilon_{\text {ocp }}$ and $C_{d}$ transients of both electrode types ( $S$ and $P$ ) are observed in the other unsaturated electrolytes. That is, (1) the $\varepsilon_{\text {ocp }}$, in the case of $\mathrm{P}$ electrode, decreases gradually in the cathodic direction; but in the case of $\mathrm{S}$ electrode, it has usually a potential plateau, (2) the dissolution rate is constant in the first stage and changes to a smaller value in the final stage which is identical with the dissolution rate of $\mathrm{A}$ electrode. However, the $C_{\mathrm{d}}$ values in the neutral electrolyte is very small compared to those in the acidic and alkaline electrolytes and has a constant value (ca. $18 \mathrm{mg}$ $\mathrm{dm}^{-3}$ ) for all electrodes in the final stage.

The experimental results obtained in three polarizing electrolytes are summarized in Tables 1 and 2. $\theta$ in Table 1 represents the oxide film thickness obtained from the optical microscopic observation of the specimen cross-sectional view. $C_{\mathrm{h}}$ in Table 2 is the amount of dissolved $\mathrm{Al}$ ion into the acidic and alkaline electrolytes at the hydrogen evolution time $t_{\mathrm{h}}$. The dissolution rates in the first stage (a) obtained from the initial linear portions of the $C_{\mathrm{d}}$ transients are also listed in Table 2.

The polarization resistances $\left(R_{\mathrm{p}}\right)$ obtained in the saturated neutral electrolyte as a function of immersion time are typically shown in Fig. 3. A decrease of $R_{\mathrm{p}}$ with the immersion time is observed for $\mathrm{P}$ electrode (solid line); however, for $\mathrm{S}$ electrode (broken line) $R_{\mathrm{p}}$ is high and relatively constant. The $R_{\mathrm{p}}$ value of $\mathrm{A}$ electrode (dotted line) is very small at all immersion time compared with those of the anodized electrodes.

The depth profiles of $\mathrm{Al}, \mathrm{P}$ and $\mathrm{S}$ in the respective anodic oxide films are shown in Figs. $4 \mathrm{a}$ and $4 \mathrm{~b}$. In the $\mathrm{P}$ electrode (Fig. $4 \mathrm{a}$ ), the Al profile shows an increase from the oxide surface to the $\mathrm{Al}$ matrix and the $\mathrm{P}$ profile has a maximum at about $1 / 3$ of the oxide film from the oxide-metal interface. In the $S$ electrode (Fig. $4 \mathrm{~b}$ ), the $\mathrm{Al}$ and $\mathrm{S}$ profiles are

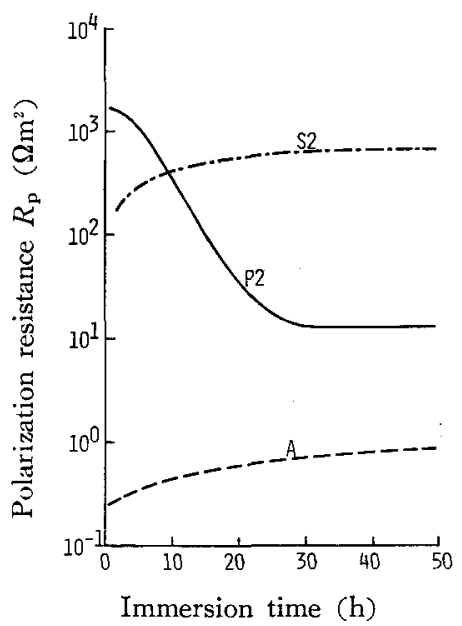

Fig. 3 Polarization resistance of electrodes in the $\mathrm{Al}$ saturated neutral buffer solution

$\mathrm{S} 2$ : Electrode anodized in sulfuric acid, P2: Electrode anodized in phosphoric acid, A : Non-anodized electrode

Table 2 Results of the open circuit dissolution of the anodic oxide films in three phosphate buffer solutions

\begin{tabular}{c|r|r|r|r|r|r|r}
\hline \hline \multirow{2}{*}{ Electrode } & \multicolumn{2}{|c|}{$t_{\mathbf{h}} / \mathrm{min}$} & \multicolumn{2}{c|}{$C_{\mathrm{h}} / \mathrm{mg} \mathrm{dm}^{-3}$} & \multicolumn{3}{c}{$\mathrm{a} / \mathrm{mg} \mathrm{dm}^{-3} \mathrm{~min}^{-1}$} \\
\cline { 2 - 8 } & acidic & alkaline & acidic & alkaline & acidic & alkaline & neutral \\
\hline P1 & 91.5 & 32.5 & 17.4 & 10.6 & 0.24 & 0.30 & 0.014 \\
P2 & 91.5 & 40.0 & 21.6 & 17.5 & 0.31 & 0.47 & 0.017 \\
P3 & 93.5 & 30.0 & 22.8 & 13.0 & 0.32 & 0.42 & 0.016 \\
P4 & 97.5 & - & 25.7 & - & 0.35 & - & 0.014 \\
P5 & 85.0 & - & 7.1 & - & 0.22 & - & 0.013 \\
\hline S1 & 26.0 & 14.0 & 26.0 & 26.5 & 1.60 & 2.24 & 0.016 \\
S2 & 34.5 & 22.0 & 57.0 & 47.0 & 2.41 & 2.91 & 0.019 \\
S3 & 37.0 & 24.0 & 73.0 & 68.0 & 3.33 & 2.24 & 0.020 \\
S4 & 37.0 & - & 57.0 & - & 2.48 & - & 0.017 \\
S5 & 23.0 & - & 28.0 & - & 2.40 & - & 0.018 \\
\hline
\end{tabular}



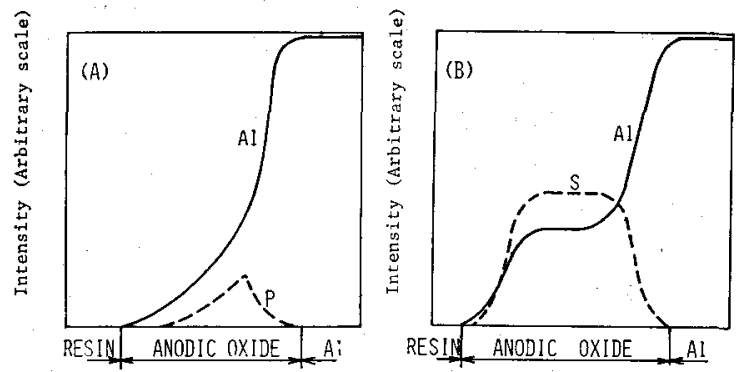

Fig. 4 Distribution profiles of $\mathrm{Al}, \mathrm{P}$ and $\mathrm{S}$ in the anodic oxide film formed in a phosphoric acid bath and in a sulfuric acid bath

(A) : P electrode, (B) : $S$ electrode

constant in the middle of the oxide film. These results, as discussed later, show that the film composition seems to be homogeneous in the $\mathrm{S}$ electrode, but it varies with the distance from the $\mathrm{Al}$ matrix in the $\mathrm{P}$ electrode.

\section{Discussion}

\subsection{Formation of oxide film in phos- phoric acid anodizing solution}

The morphology and the composition of the PAA oxide film have been yielded in some studies $^{7 \sim 9)}$ with different anodizing conditions. The oxide film thickness is generally as a function of the anodizing time and the solution concentration. In the present work, it should be noted that the oxide film thickness $(\theta)$ was independent of the anodizing time in phosphoric acid at a constant cd; whereas, $\theta$ increased linearly with anodizing time in sulfuric acid (1, 2 and 3 electrodes in Table 1 ). Alternatively, when both the anodizing cd and time were changed giving a constant anodizing charge (2, 4 and 5 electrodes in Table 1), $\theta$ was nearly constant for $\mathrm{S}$ electrodes as predicted, but it was different for $\mathrm{P}$ electrodes. In addition, the ratio values of $C_{\mathrm{o}} / \theta$ was nearly 1.5 and 5 for $\mathrm{P}$ and $\mathrm{S}$ electrodes, respectively, and independent of the anodizing conditions. This suggests that $C_{\mathrm{o}}$ also represents the oxide film thickness.

It has been known that the so-called field-assisted dissolution participated during anodization was a key mechanism of porous oxide growth ${ }^{17}$. According to this theory, once the porous structure initiated, each pore grew by preferential oxidation and dissolution at the bottom of the pore where the field strength was greatest. The anodizing voltages of $\mathrm{P}$ electrodes were much higher than those of $\mathrm{S}$ electrodes (Table 1 ), and, as a result, the high dissolution at the pore bottom hindered the increase of the oxide film thickness and provided a constant thickness within this anodizing time range. The constant film thickness after a certain anodizing time was also reported in some works ${ }^{1,9}$, although a smaller anodizing potential has been applied. The small anodizing voltages of $\mathrm{S}$ electrodes caused reasonably a lower dissolution rate and provided a linear increase of the film thickness. A similar result was reported by Thompson, et al. ${ }^{11)}$ using an electron microscopy method. The results obtained for oxides formed in constant charge were also understood by the above discussion.

\subsection{Open circuit dissolution of oxide fi- Im in phosphate buffer solutions}

The open circuit disolution of porous oxide film has been investigated in some works ${ }^{18,197}$ and may be chemical rather than electrochemical in nature; however, it remains an open question. It is noted that the dissolving solutions in these experiments were unbuffered ones. The chemical dissolution, in which whether anion is involved or not, should be dependent on the $\mathrm{pH}$ of the dissolving solution. Thus in this work, it is reasonable to consider that the dissolution rate in the acidic and alkaline buffer solutions is very much higher than that in the neutral solution.

The dissolution rates (a), obtained from the initial linear portions of the $C_{\mathrm{d}}$ transients; of $\mathrm{P}$ electrodes in the acidic and alkaline solutions were smaller than those of $\mathrm{S}$ electrodes (Table 2 ); even if the difference of the ratios $C_{\mathrm{o}} / \theta$ (Table 1) was considered. This suggests that the PAA oxide film is more corrosion resistive in acidic and alkaline media than the sulfuric acid anodized film. On the other hand, in the neutral solution, the dissolution rates of $\mathrm{P}$ electrodes were higher than those of $\mathrm{S}$ electrodes, if also taking consideration of the $C_{\mathrm{o}} / \theta$ values.

The amount of dissolved $\mathrm{Al}$ at $t_{\mathrm{h}}\left(C_{\mathrm{h}}\right)$ was almost the same value as the corresponding amount of Al within oxide film $\left(C_{0}\right)$ (Tables 1 and 2). This indicates that, in the acidic and alkaline solutions, the original oxide film was 
dissolved completely at $t_{\mathrm{h}}$; indeed, after this period, the dissolution rate decreased to the value of the bare $\mathrm{A}$ electrode (Figs. 1 and 2). This decrease suggests the presence of the underlying barrier layer. The more pronounced (longer time) decrease for $\mathrm{P}$ electrode than for $\mathrm{S}$ electrode, as seen in Figs. 1 and 2, suggests that the barrier layer thickness of $\mathrm{P}$ electrode was thicker. This fact is reasonable since the applied voltage of $\mathrm{P}$ electrode was higher than that of $\mathrm{S}$ electrode. When $t_{\mathrm{h}}$ became long, the $C_{\mathrm{h}}$ value tended to increase and this may be caused by the dissolution from the $\mathrm{Al}$ substrate before $t_{\mathrm{h}}$.

According to Abd Rabbo et al. ${ }^{20)}$, the phosphate anions $\left(\mathrm{H}_{2} \mathrm{PO}_{4}{ }^{-}, \mathrm{HPO}_{4}{ }^{2-}\right.$, etc. $)$ was strong chemisorptive and degraded the $\mathrm{Al}$ anodic oxide in a neutral phosphate solution. The degradation of the anodic oxide may become apprec iably to the above chemical dissolution in the unsaturated neutral solution and should be considered even in the saturated neutral solution. The higher dissolution rate for $\mathrm{P}$ electrodes than for $\mathrm{S}$ electrodes in the unsaturated neutral solution, as described above, was interpreted by this aggressive nature and by existence of active sites containing in the oxide film. The studies on electroplating ${ }^{3,4)}$ and on corrosion ${ }^{157}$ of anodic oxide film had suggested there are many active sites at the surface of the PAA oxide. The film degradation converging upon these active sites caused the decrease of the polarization resistance in the saturated neutral solution (Fig. 3), in which the chemical dissolution was negligible. Namely, the polarization resistance $\left(R_{\mathrm{p}}\right)$ of $\mathrm{P}$ electrode was very high at the very early stage, but decreased with immersion time; while the polarization resistance of $\mathrm{S}$ electrode was constantly high throughout the experiment. In addition, the initial $R_{\mathrm{p}}$ value right after the immersion was higher for $\mathrm{P}$ electrodes than for $\mathrm{S}$ electrodes. This result was substantiated by the fact that the barrier layer of $\mathrm{P}$ electrode was thicker as noted above. The nature and the formation of the active sites will be discussed in detail in a further study ${ }^{21)}$.

\subsection{Reration between the $e_{\text {ocp }}$ transients and the film composition}

The distribution of $\mathrm{Al}, \mathrm{P}$ and $\mathrm{S}$ in the cross- sectional view of the oxide film were quite different for the two electrodes (Fig. 4). These distributions' have been investigated in a number of works: with an indirect method using the dissolution experiment in an acidic solution $^{19)}$ and with a direct method using many electron spectroscopy analyses, e.g., Auger electron spectroscopy ${ }^{1,22,23)}$, secondary ion mass spectroscopy ${ }^{20)}$, ion scattering spectroscopy ${ }^{24)}$ and $\mathrm{X}$-ray microanalyzer analysis ${ }^{25}$. There were some discrepancies between these studies; however, the common picture of the distributions of $\mathrm{Al}, \mathrm{O}$ and anions ( $\mathrm{P}$ and $\mathrm{S}$ ) were as follows. (1) The distribution profiles of $\mathrm{Al}$ and $\mathrm{O}$ were relatively identical, indicating that the stoichiometry of the anodic oxide was invariant with depth, and were nearly constant through the oxide film. (2) $\mathrm{P}$ distributed largely within the region adjacent to the oxide surface and decreased gradually in the oxide film. (3) $\mathrm{S}$ distributed uniformly through the oxide film.

In the analysis of the depth profiles obtained with a X-ray microanalyzer, the amplitudes of $\mathrm{Al}$ and anions were small in the surface region (Fig. 4). This finding is in agreement with the result of Takahashi, et al. ${ }^{25)}$ who studied various anodic oxide on pure $\mathrm{A}_{1}$ and its alloy with the same method. This fact has been interpreted by the funnel shape of the pores which became large as near as the oxide surface $^{26)}$. Furthermore, as a characteristic of this method, the information obtained was one of relatively large region, as noted above, and seemed to be dependent closely upon the oxide surface morphology. Taking consideration of this characteristic, the distributions of $\mathrm{Al}, \mathrm{P}$ and $\mathrm{S}$ in Fig. 4 may be coincidient with the results described above.

The $\varepsilon_{\text {ocp }}$ transients with the immersion time was also quite different (Figs. 1 and 2) and could be explained with knowing the film composition ${ }^{27)}$. Namely, in the case of $\mathrm{S}$ electrode (Fig. 2), the oxide film was homogeneous; therefore, the open circuit dissolution of the porous layer caused the reduction of film thickness, but not the change of film composition. The potential plateau at ca. $-1.0 \mathrm{~V}$ was observed until the porous layer had completely dissolved off and followed by the drastic potential decrease before the hydrogen evolu- 
tion. On the other hand, in the case of $\mathrm{P}$ electrode (Fig, 1), the composition of the porous layer was changed with depth; therefore, upon the open circuit dissolution from the film surface, the $\varepsilon_{\text {ocp }}$ changed gradually with the immersion time and the potential plateau was not observed.

This explanation of the $\varepsilon_{\text {ocp }}$ transients is, of course, not yet sufficient. Other factors such as impurities or alloy components, film morphology etc. may play a role in the open circuit dissolution. Further studies along this line are needed to clarify this dissolution type.

Finally, the saturated neutral phosphate buffer solution is concluded as a suitable electrolyte for an electrochemical study, specially for an evaluation of corrosion resistance ${ }^{21)}$ because the chemical dissolution of anodic oxide during immersion in this solution is thermodynamically impossible. The aggressive nature of phosphate anions converging upon the active sites within oxide film might occur in this system; however, it may be negligible in a measurement during a short period of time.

\section{References :}

1) J.S. Solomon and D.E. Hanlin, Appl. Surface Sci. 4, 307 (1980).

2）日本特許公報，昭 46-26521 (1971)

3) A. Akiyama, K. Yasuhara, T. Tanaka and T. Saji, Plating 58, 594 (1971).

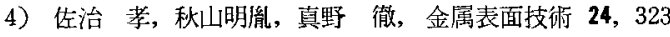
(1973).

5) J.P. O'Sullivan and G.C. Wood, Proc. Roy. Soc. A 317, 511 (1970).

6) G.E. Thompson, R.C. Furneaux, G.C. Wood, J.A. Richardson and J.S. Goode, Nature 272, 433 (1978).
7) G.E. Thompson, R.C. Furneaux, J.S. Goode and G.C. Wood, Trans. Ins. Met. Finish. 56, 159 (1978).

8）高橋英明，永山政一，日本化学会誌 453 (1974).

9) J.S. Ahearn, T.S. Sun, C. Froede, J.D. Venables and R. Hopping, SAMPE Quarterly, 39 (1980).

10) K.V. Heber, Electrochim. Acta 23, 127 (1978).

11) G.E. Thompson, R.C. Furneaux and G.C. Wood, Trans: Ins. Met. Finish. 55, 117 (1977).

12) H. Takahashi and M. Nagayama, Electrochim. Acta 23, 279 (1978).

13) A.K. Vijh, J. Phys. Chem. 13, 506 (1969).

14) N.D. Greene, Electrochemical Electrode Kinetics, New York (1965).

15） P.T. Thanh, A. Akiyama and T. Saji, 防食技術 30, 265 (1981).

16) Snell and Snell, Colometric Methods of Analysis, Vol. IIA (1959).

17) J.M. Diggle, Oxide and Oxide Films, Vol. 2, p. 354 (1973), Marcel Dekker, New York.

18) J.W. Diggle, T.C. Downie and C.W. Goulding, J. Electrochem. Soc. 116, 1347 (1969).

19) M. Nagayama and K. Tamura, Electrochim. Acta 12, 1097 (1967).

20) M.F. Abd Rabbo, J.A. Richardson, G.C. Wood and C.K. Jackson, Corr. Sci. 16, 677 (1976); 16, 689 (1976).

21) P.T. Thanh, A. Akiyama and T. Saji, Electrochim. Acta, in preparation.

22) R. Bador, G. Bouyssoux, M. Romand, J.S. Solomon and W.L. Baun, Mater. Res. Bull. 12, 197 (1977).

23) T.S. Sun, D.K. Mc Namara, J.S. Ahearn, J.M. Chen, B. Ditchek and J.D. Venables, Appl. Surface Sci. 5, 406 (1980).

24) H.H. Stekblow and D.L. Malm, Corr. Sci. 19, 469 (1979).

25）高橋俊郎，長野年宏，和田健二，池万谷正志，田賀井秀 夫，金属表面技術 23，18(1972).

26) K. Huber, J. Colloid. Sci. 3, 3, 197 (1948).

27) K.J. Vetter, Electrochim. Acta 16, 1923 (1971).

(Received Jun. 16, 1981 ; Accepted Aug. 26, 1981)

電気化学協会電池技術委員会編 B 5 判 本文 155 ページ 頒布価 5,000 円（送料 300 円）

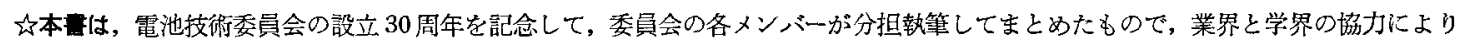
総合的, かつ普遍的に, 電池全般の現況が紹介されています. 省資源, 省エネルギーはエネルギーの有效利用と両輪をなすもので あり，高いエネルギー効率字特徵とする電池䒺によるエネルギー変換法は，今後安すます重要なるのとなり，乙かも移動用，携带 用電池としての電池の応用は拡大されるばかりであります。本書が大方のお役に立てうればと願っており市。

々内 容 ○一次電池の技術 ○マンカ゚ン乾電池 ○酸化銀電池 ○リチウム電池 ○その他の一次電池 ○二次電池の技術 ○鉛

蓄電池 $○$ ニッルカドミウム蓄電池 ○その他の二次電池 ○燃料電池 ○太陽電池 ○資料

公申込先 5655 吹田市山田质 2-1 大阪大学工学部応用化学教室内 電気化学協会電池技術委員会 (86-877-5111 内線 4301), @100 東京都千代田区有楽町 1-12-1 新有楽町ビル 電気化学協会（203-214-6001） 